\title{
Analisis Determinan Profit Distribution Management Bank Umum Syariah Periode 2013-2016
}

\author{
Muniya Alteza \\ Fakultas Ekonomi Universitas Negeri Yogyakarta \\ Email: $\underline{m}$ alteza@uny.ac.id
}

\begin{abstract}
This study aimed to examine the variables as determinant of Profit Distribution Management of the Sharia Commercial Bank in Indonesia in the 2013-2016 periods. The variables studied consisted of the proportion of third party funds, the effectiveness of third party funds, the capital adequacy ratio and the ratio of operational costs to operating income. Samples were collected using purposive sampling technique. Data analysis technique used is multiple linear regression. The results showed that the proportion of third party funds, the effectiveness of third party funds which was proxied by Financing to Deposit Ratio (FDR) and Capital Adequacy Ratio (CAR) individually had a positive and significant effect on Profit Distribution Management. In addition it was found that the ratio of operational costs to operating income (BOPO) had no significant effect on Profit Distribution Management. The value of Adjusted $R^{2}$ was 0,254 which means that variation of Profit Distribution Management which can be explained by variable used in research was $25,4 \%$ while the rest equal to $74,6 \%$ explained by other variables not used in the model of this research.
\end{abstract}

Keywords: Profit Distribution Management, proportion of third party funds, FDR, CAR, ratio of operational costs to operating income.

\begin{abstract}
Abstrak
Penelitian ini bertujuan untuk menguji variabel sebagai determinan Profit Distribution Management pada Bank Umum Syariah di Indonesia periode 2013-2016. Adapun variabel yang diteliti terdiri atas proporsi dana pihak ketiga, efektivitas dana pihak ketiga, rasio kecukupan modal dan rasio biaya operasional terhadap pendapatan operasional. Sampel dikumpulkan menggunakan teknik purposive sampling. Teknik analisis data yang digunakan adalah regresi linear berganda. Hasil penelitian menunjukkan bahwa proporsi dana pihak ketiga, efektivitas dana pihak ketiga yang diproksikan dengan Financing to Deposit Ratio (FDR) dan rasio kecukupan modal (CAR) secara individual berpengaruh positif dan signifikan terhadap Profit Distribution Management. Selain itu ditemukan bahwa rasio biaya operasional terhadap pendapatan operasional (BOPO) tidak berpengaruh signifikan terhadap Profit Distribution Management. Nilai Adjusted $\mathrm{R}^{2}$ dalam penelitian ini sebesar 0,254 yang bermakna bahwa variasi Profit Distribution Management yang dapat dijelaskan oleh variabel yang digunakan dalam penelitian sebesar 25,4\% sedangkan sisanya sebesar $74,6 \%$ dijelaskan oleh variabel lain yang tidak digunakan dalam model penelitian ini.
\end{abstract}

Kata Kunci: Profit Distribution Management, proporsi dana pihak ketiga, FDR,CAR, BOPO 


\section{A. Pendahuluan}

Bank memegang peranan penting sebagai lembaga intermediaries yang menghimpun dana dari masyarakat dan menyalurkannya kepada pihak yang membutuhkan. Berdasarkan sistem operasionalnya, perbankan Indonesia dibagi menjadi dua macam sistem perbankan yakni sistem perbankan konvensional dan sistem perbankan syariah. Sistem perbankan konvensional menggunakan bunga dalam sistem operasionalnya. Hal ini berbeda dengan sistem perbankan syariah yang beroperasi berdasarkan pada prinsip-prinsip syariah Islam berlandaskan pada Al-Qur'an dan Hadits.

Perkembangan Bank Syariah di Indonesia sendiri cukup pesat. Hal ini terlihat dari data Otoritas Jasa Keuangan bahwa sampai dengan bulan Oktober 2016, di Indonesia terdapat 13 Bank Umum Syariah (BUS), 21 Unit Usaha Syariah (UUS), dan 165 Bank Pembiayaan Rakyat Syariah (BPRS). Selain itu juga diketahui bahwa total aset bank syariah per Oktober 2016 mencapai Rp241,629 triliun, di mana angka ini berarti telah meningkat sekitar 13\% dari tahun 2015. Jumlah dana yang berhasil dihimpun oleh Bank Syariah mencapai Rp 199,642 triliun dan sekitar Rp 173,299 triliun telah disalurkan ke masyarakat dalam bentuk pembiayaan.

Dalam proses penghimpunan dana maupun penyaluran dana, bank syariah menerapkan sistem bagi hasil dengan cara perhitungan bagi pendapatan (revenue sharing), bagi laba (profit sharing) maupun bagi risiko (risk sharing). Sistem bagi hasil membuat besar kecilnya keuntungan yang diterima nasabah (shahibul maal) mengikuti besar kecilnya keuntungan bank syariah. Penyaluran dana deposan yang terkumpul akan ditempatkan oleh bank syariah ke sektor-sektor usaha produktif (pembiayaan) yang menghasilkan keuntungan. Apabila hasil usaha yang diperoleh semakin tinggi maka semakin besar pula keuntungan yang dibagikan bank kepada dan deposannya. Hal ini juga berlaku sebaliknya, jika hasil usaha yang diperoleh semakin kecil maka semakin kecil pula keuntungan yang dibagikan bank kepada deposannya. Bank syariah dapat memperoleh keuntungan bagi hasil apabila dana nasabah diinvestasikan terlebih dahulu ke dalam bentuk usaha. Hal ini berbeda dengan simpanan nasabah di bank konvensional. Meskipun bank tidak menyalurkan simpanan nasabah sebagai 
kredit tetapi bank tetap berkewajiban memberikan bunga simpanan. Sebaliknya keuntungan yang diperoleh bank juga tidak dibagikan kepada deposannya. Sebesar apapun jumlah keuntungan bank konvesional, deposan hanya dibayar sejumlah presentase dari dana yang disimpannya saja (Rini, 2000).

Agar dapat bersaing dengan bank konvensional yang selama ini lebih mendominasi industri perbankan di Indonesia maka bank syariah wajib selalu berusaha meningkatkan kinerja keuangannya, termasuk kemampuan mengelola dana dan memberikan bagi hasil yang maksimal. Profit distribution adalah pembagian keuntungan bank syariah kepada deposan berdasarkan nisbah yang disepakati setiap bulannya. Profit distribution ini diatur berdasarkan produk yang menjadi pilihan deposan terhadap bank, serta persetujuan nisbahnya. Mawardi (2005) menerjemahkan profit distribution sebagai distribusi hasil usaha atau distribusi pendapatan sementara Antonio (2001) menyebutnya sebagai distribusi bagi hasil. Menurut Bank Indonesia, kewajiban bank syariah dalam membagi keuntungan yang didapat dengan memanfaatkan dana nasabah melalui pembiayaan berdasarkan nisbah yang disekapati setiap periodenya disebut Distribusi Bagi Hasil. Secara umum Profit Distribution Management (PDM) dapat diartikan sebagai aktivitas bagaimana seorang manajer dapat mengelola dan mendistribusikan laba untuk memenuhi kewajiban bagi hasil bank syariah kepada nasabahnya (Mulyo dan Mutmainah, 2013). Profit Distribution Management merupakan suatu aktivitas wajib berdasarkan peraturan Perbankan Syariah oleh Bank Indonesia yang menyatakan bahwa distribusi bagi hasil adalah kewajiban bank syariah dalam pembagian keuntungan kepada nasabah berdasarkan nisbah yang telah disepakati. Hal ini dikarenakan dalam Profit Distribution Management, bank syariah melakukan perhitungan pembagian usaha antara shahibul maal (pemberi dana) dengan mudharib (pengelola dana) sesuai dengan nisbah yang disepakati di awal akad.

Di Indonesia, manajer bank syariah melakukan Profit Distribution Management yang mengacu pada suku bunga bank konvensional. Hal ini terkait erat dengan tipe deposan di Indonesia. Deposan bank syariah di Indonesia terbagi dalam beberapa segmentasi pasar. Karim dan Afif (2006) menyatakan bahwa di Indonesia ditemukan tiga segmentasi pasar, yaitu 
sharia loyalist (terdiri dari penganut agama yang patuh), floating segment (kombinasi agama dan kekuatan pasar) dan conventional loyalist. Hasil survei juga menyebutkan bahwa 70\% deposan perbankan syariah adalah deposan yang berada pada floating segment, yang sensitif pada tingkat keuntungan. Hal ini diperkuat oleh temuan studi Yahya (2011) yang menyimpulkan bahwa perilaku menabung di bank syariah paling dipengaruhi oleh tingkat bagi hasil (profit distribution). Penelitian Husnelly (2003) dan Mangkuto (2004) juga menegaskan bahwa faktor yang menjadi pertimbangan masyarakat menginvestasikan dananya di bank syariah adalah faktor return bagi hasil. Berdasarkan temuan dari beberapa penelitian tersebut mengimplikasikan bahwa bank syariah harus memperhatikan Profit Distribution Management.

Menurut Farook et al. (2009), Indonesia dan tiga negara lainnya yaitu Bahrain, Pakistan, dan Saudi Arabia merupakan negara yang rata-rata melakukan Profit Distribution Management yang tinggi. Hal ini disebabkan karena nasabah saat ini lebih mengutamakan tingkat keuntungan yang ditawarkan oleh bank syariah tersebut, sehingga manajer harus dapat menjaga kualitas Profit Distribution yang dihasilkan. Aktivitas yang dikelola oleh manajer tersebut dilakukan agar tidak terjadi displacement fund yaitu kejadian dimana nasabah memilih untuk memindahkan dana yang mereka miliki ke bank yang lain. Apabila tingkat bagi hasil yang diberikan bank syariah berbeda jauh dibandingkan suku bunga konvensional, maka nasabah lebih suka menyimpan dananya di bank konvensional. Berkurangnya penghimpunan dana nasabah mengakibatkan bank syariah kehilangan sumber dana utama sehingga dapat memengaruhi jalannya fungsi bank sebagai lembaga intermediasi. Oleh karena itulah bank syariah perlu mengetahui determinan faktor-faktor yang memengaruhi Profit Distribution Management.

Proporsi dana pihak ketiga adalah variabel yang menggambarkan seberapa besar ketergantungan bank terhadap dana titipan masyarakat yang berupa tabungan, giro atau deposito (Mulyo dan Mutmainah, 2013). Dana pihak ketiga merupakan sumber utama dana yang akan disalurkan sebagai pembiayaan bank syariah. Jika dana tidak cukup, bank tidak mampu melakukan fungsinya dengan maksimal 
atau bahkan menjadi tidak berfungsi sama sekali. Semakin tinggi proporsi dana pihak ketiga yang diterima oleh bank, maka Profit Distribution Management yang dilakukan semakin baik. Dengan demikian proporsi dana pihak ketiga berpengaruh positif terhadap Profit Distribution Management.

Efektivitas dana pihak ketiga merupakan cerminan dari fungsi intermediasi bank, yaitu dalam menyalurkan dana pihak ketiga ke pembiayaan. Efektivitas dana pihak ketiga dapat diukur dengan Financing to Deposit Ratio (FDR). Bank Indonesia sendiri mematok rasio FDR berkisar antara 85\%$100 \%$. Semakin tinggi rasio ini maka tingkat kesehatan bank juga semakin baik karena pembiayaan yang disalurkan bank dari dana yang berhasil dihimpun berlangsung lancar, sehingga pendapatan bank semakin meningkat. Oleh karena itu disimpulkan bahwa efektivitas dana pihak ketiga berpengaruh positif terhadap Profit Distribution Management.

\section{Capital Adequacy Ratio (CAR)} merupakan rasio yang digunakan untuk mengukur kecukupan modal. Rasio ini menggambarkan kemampuan bank dalam mempertahankan modal yang mencukupi untuk menutup risiko kerugian yang mungkin timbul dari penanaman dana dalam aset produktif yang mengandung risiko, serta untuk pembiayaan dalam aset tetap dan investasi. Semakin besar rasio ini, maka kesehatan bank dikatakan membaik. Hal ini bermakna bahwa modal yang dimiliki bank mampu menutupi risiko kerugian yang timbul dari penanaman dana sehingga memudahkan manajer bank melakukan Profit Distribution Management yang mengacu pada suku bunga dikarenakan bank sedang dalam kondisi yang aman. Berdasarkan uraian tersebut maka kecukupan modal yang diproksikan dengan Capital Adequacy Ratio berpengaruh positif terhadap Profit Distribution Management.

Determinan lain dari Profit Distribution Management adalah rasio Biaya Operasional terhadap Pendapatan Operasional (BOPO). Rasio ini digunakan untuk mengukur tingkat efisiensi suatu bank, dimana semakin tinggi BOPO bermakna bahwa bank semakin tidak efisien. Beban operasional yang semakin besar mengakibatkan tingkat keuntungan yang diterima oleh bank syariah semakin rendah. Hal ini pada akhirnya mengakibatkan bagi hasil yang diberikan kepada nasabah juga menjadi semakin 
kecil. Apabila beban operasional yang harus ditanggung bank syariah semakin besar Dengan demikian semakin tinggi tingkat BOPO maka akan berpengaruh negatif terhadap Profit Distribution Management.

Beberapa penelitian sebelumnya telah dilakukan untuk menguji faktorfaktor yang memengaruhi besarnya Profit Distribution Management dengan hasil yang bervariasi. Penelitian Rizaludin dan Dodik (2013) mengidentifikasi pengaruh positif proporsi dana pihak ketiga dan umur bank syariah terhadap Profit Distribution Management, dan pengaruh negatif rasio biaya operasional terhadap pendapatan operasional serta financing to deposit ratio terhadap Profit Distribution Management. Mulyo dan Mutmainah (2013) dalam penelitiannya menemukan bahwa kecukupan modal, pembiayaan non investasi, dan penyisihan penghapusan aktiva produktif berpengaruh positif terhadap Profit Distribution Management. Variabel lainnya yaitu efektivitas dana pihak ketiga dan proporsi dana pihak ketiga berpengaruh negatif terhadap Profit Distribution Management, sedangkan risiko pembiayaan, pertumbuhan produk domestik bruto, dan umur bank tidak berpengaruh terhadap Profit Distribution Management. Hasil yang berbeda ditemukan dalam pengujian Wafaretta dan Rosidi (2015), yang membuktikan bahwa komposisi aset dan proporsi dana pihak ketiga berpengaruh positif terhadap Profit Distribution Management. Determinan lain yaitu efektivitas dana pihak ketiga dan umur bank berpengaruh negatif terhadap Profit Distribution Management. Penelitian Hermanu dan Setiawati (2015) menunjukkan bahwa menunjukkan bahwa kecukupan modal, dan risiko pembiayaan berpengaruh negatif terhadap Profit Distribution Management sedangkan variabel efektifitas dana pihak ketiga, proporsi pembiayaan non investasi, proporsi dana pihak ketiga, penyisihan penghapusan aktiva produktif, dan umur bank tidak berpengaruh terhadap Profit Distribution Management. Sementara penelitian Rifadil dan Muniruddin (2017) memperlihatkan bahwa kecukupan modal dan risiko pembiayaan berpengaruh positif terhadap Profit Distribution Management. Variabel lainnya yaitu efektivitas dana pihak ketiga dan umur bank tidak berpengaruh terhadap Profit Distribution Management. Dari review penelitian tersebut terlihat bahwa 
penelitian determinan Profit Distribution Management masih memberikan kesimpulan yang belum konklusif sehingga masih diperlukan pengujian lebih lanjut. Oleh karena itu penelitian ini bertujuan menguji kembali determinan Profit Distribution Management pada bank syariah di Indonesia. Adapun variabel yang diteliti terdiri atas proporsi dana pihak ketiga, efektivitas dana pihak ketiga, kecukupan modal dan rasio biaya operasional terhadap pendapatan operasional.

\section{B. Metode Penelitian}

Penelitian ini merupakan penelitian asosiatif kausal yaitu penelitian yang dimaksudkan untuk mengungkapkan permasalahan yang bersifat hubungan sebab akibat antara dua variabel atau lebih (Sugiyono, 2008). Pendekatan dalam penelitian ini adalah pendekatan kuantitatif dengan menggunakan data yang berbentuk angka pada analisis data statistiknya.

Populasi dalam penelitian ini mencakup seluruh perusahaan perbankan syariah yang tercatat di Otoritas Jasa Keuangan tahun 2013-2016. Sampel penelitian diambil dengan menggunakan purposive sampling dengan kriteria sebagai berikut: 1) Bank umum syariah yang mempublikasikan laporan keuangan triwulan periode triwulan I tahun 2013 sampaui triwulan III tahun 2016; 2) Bank umum syariah yang memiliki kelengkapan data yang dibutuhkan dalam penelitian ini.

Variabel dependen dalam penelitian ini adalah Profit Distribution Management (PDM), yaitu aktivitas yang dilakukan manajer dalam mengelola pendistribusian laba untuk memenuhi kewajiban bagi hasil bank syariah kepada nasabahnya. Mengacu pada model penelitian penelitian Sundararajan (2005) dan Farook et al. (2009), penelitian ini menggunakan asset spread sebagai metode untuk menghitung PDM yang mengacu pada suku bunga. Asset spread merupakan indikator paling kuat untuk menghitung PDM karena mempertimbangkan seluruh pendapatan dan beban dan menyediakan spread antara total asset return dari aset bank dan distribusi yang diberikan kepada deposan. Semakin tinggi asset spread mengindikasikan adanya pendistribusian laba kepada deposan yang jauh dari asset return sehingga hal tersebut memperkuat adanya tindakan PDM yang mengacu pada suku bunga. Asset spread adalah absolute spread antara Return On 
Asset (ROA) dan average Return On Investment rata-rata return bagi hasil deposan. Account Holder (ROIAH) yang merupakan Perhitungannya dilakukan sebagai berikut:

$$
\begin{aligned}
& \mathrm{PDM}=[\mathrm{ROA}-\text { Average ROIAH }] \\
& \text { Average ROIAH }=\frac{\text { Pendapatan yang harus dibagi }}{\text { Saldo rata }- \text { rata instrumen bagi hasil deposan }} \\
& \mathrm{ROA}=\frac{\text { Laba sebelum pajak }}{\text { Totalaset }}
\end{aligned}
$$

Variabel independen dalam penelitian ini adalah faktor-faktor yang memengaruhi besaran PDM yaitu:

1. Proporsi dana pihak ketiga. Dana pihak ketiga menurut UU No 10 Tahun 1998 yaitu pemberian kredit atau pembiayaan yang bersumber

$$
\text { Proporsi dana pihak ketiga }=\frac{\text { Jumlah dana pihak ketiga }}{\text { Total aset }}
$$

2. Efektivitas dana pihak ketiga. Variabel ini menggambarkan fungsi perantara yang dijalankan oleh perbankan syariah dan diukur menggunakan financing to deposit ratio (FDR). Perhitungannya dilakukan sebagai berikut:

FDR $=\frac{\text { Jumlah penyaluran pembiayaan }}{\text { Jumlah dana pihak keti ga }}$

3. Kecukupan modal merupakan alat untuk mengukur kewajiban dari dana masyarakat yang disimpan pada bank. Proporsi dana pihak ketiga diukur melalui presentase dana nasabah terhadap total aset. Pengukuran variabel ini mengacu pada Farook et al. (2009) yaitu:

penyediaan modal minimum bank maupun dalam memenuhi kewajiban jangka panjang atau kemampuan bank untuk memenuhi kewajiban-kewajiban jika terjadi likuidasi. Kecukupan modal dicerminkan melalui Capital Adequacy Ratio (CAR). Perhitungannya dilakukan sebagai berikut: 


$$
\mathrm{CAR}=\frac{\text { Modal bank }}{\text { Jumlah Akt iva Tertimban g Menurut Risiko (ATMR) }}
$$

4. Biaya Operasional terhadap berikut:

Pendapatan Operasional. BOPO $\mathrm{Y}=\beta_{0}+\beta_{1} \mathrm{X}_{1}+\beta_{2} \mathrm{X}_{2}+\beta_{3} \mathrm{X}_{3}+\beta_{4} \mathrm{X}_{4}+\mathrm{e}$

merupakan rasio untuk $\mathrm{Y}=$ Profit Distribution Margin (PDM)

membandingkan antara biaya $\mathrm{X}_{\mathrm{l}}=$ Proporsi Dana Pihak Ketiga (PDPK)

operasional dengan pendapatan $\mathrm{X}_{2}=$ Financing to Deposit Ratio (FDR)

operasional dalam mengukur $\mathrm{X}_{3}=$ Capital Adequacy Ratio (CAR)

tingkat efisiensi dan kemampuan

bank dalam menunjang kegiatan

operasional (Rivai dan Arifin, 2010).

Variabel ini dihitung sebagai

berikut:

$\mathrm{BOPO}=\frac{\text { Jumlah biaya operasiona } 1}{\text { Jumlah pendapatan operasiona } 1}$

Jenis data yang digunakan berupa data sekunder yang bersifat historis yaitu laporan keuangan triwulanan yang telah diterbitkan oleh bank yang bersangkutan periode triwulan I tahun 2013 sampaui triwulan III tahun 2016. Metode pengumpulan data yang digunakan yaitu melalui metode dokumentasi. Metode ini dilakukan dengan menggunakan data yang berasal dari dokumen-dokumen yang sudah ada. Penelitian ini menggunakan teknik analisis melalui analisis regresi linear

$\mathrm{X}_{4}=$ Biaya Operasional terhadap Pendapatan Operasional (BOPO)

$\mathrm{e}=$ error term

Sebelum dilakukan pengujian terhadap hipotesis terlebih dahulu dilakukan uji prasyarat analisis berupa uji asumsi klasik, yang terdiri atas:

1. Uji normalitas, bertujuan untuk menguji apakah dalam model regresi, variabel pengganggu atau residual memiliki distribusi normal. Pengujian normalitas atas residual model regresi dilakukan dengan uji One Sample Kolmogorov Smirnov. Residual dinyatakan terdistribusi normal apabila nilai signifikansi lebih besar daripada 5\%.

2. Uji autokorelasi, bertujuan untuk menguji apakah dalam model regresi linier ada korelasi antara kesalahan penganggu pada periode $t$ 
dengan kesalahan penganggu pada periode $t-1$ (sebelumnya). Pengujian dilakukan melalui uji Durbin Watson. Data tidak terkena autokorelasi apabila nilai DW yang dihasilkan dari pengujian terletak antara du dan 4-du.

3. Uji multikolinearitas, bertujuan mengetahui apakah dalam model regresi ditemukan adanya korelasi antar variabel independen. Pengujian dilakukan dengan melihat nilai VIF dan Tolerance. Jika nilai VIF < 10 dan nilai Tolerance > 0,0l, maka tidak terjadi multikolinearitas pada variabel independen yang digunakan dalam penelitian.

4. Uji heteroskedastisitas, bertujuan untuk mengetahui ketidaksamaan variance dari residual satu ke pengamatan lain. Pengujian dilakukan melalui uji Glejser yaitu meregrasikan variabel independen dengan nilai absolut residual. Data diiindikasikan terkena heteroskedastisitas apabila nilai signifikansi variabel independen kurang dari 5\%.
Pengujian hipotesis dilakukan melalui uji parsial (uji t). Hipotesis akan diterima apabila koefisien regresi memiliki arah yang sama sesuai hipotesis dan nilai signifikansi yang diperoleh dari pengujian lebih kecil dibandingkan tingkat signifikansi yang digunakan sebesar 5\%. Selain itu juga dilakukan pengujian kelayakan model regresi yang dilihat dari uji $\mathrm{F}$ dan nilai Adjusted $R^{2}$. Model penelitian layak digunakan apabila nilai signifikansi F lebih kecil dibandingkan tingkat signifikansi yang digunakan sebesar 5\%. Nilai Adjusted $R^{2}$ memperlihatkan kemampuan model dalam menjelaskan variasi variabel dependen Profit Distribution Management. Model semakin baik digunakan untuk prediksi apabila nilai Adjusted $R^{2}$ semakin tinggi.

\section{Hasil Penelitian dan Pembahasan}

Penelitian ini menggunakan data yang bersumber dari laporan keuangan bank umum syariah yang terdaftar di Otoritas Jasa Keuangan dalam periode triwulan I tahun 2013 sampai dengan triwulan III tahun 2016. Sampel dipilih dengan menggunakan teknik purposive sampling sebagaimana terlihat dalam tabel 1. 
Tabel 1. Sampel Penelitian

\begin{tabular}{|c|c|c|}
\hline No. & Keterangan & Jumlah \\
\hline 1 & $\begin{array}{l}\text { Bank umum syariah yang } \\
\text { terdaftar di Otoritas Jasa } \\
\text { Keuangan } \\
\text { menerbitkan laporan } \\
\text { keuangan } \\
\text { periode periode } \\
\text { I triwulan } \\
\text { dengan triwulan } \\
\text { tahun 2013 sampai } \\
\text { konsisten dan telah } \\
\text { dipublikasikan }\end{array}$ & 13 \\
\hline 2 & $\begin{array}{lr}\text { Bank Umum Syariah } \\
\text { (BUS) yang tidak } \\
\text { menerbitkan laporan } \\
\text { keuangan triwulan secara } \\
\text { konsisten selama periode } \\
\text { penelitian dan/atau tidak } \\
\text { memiliki data yang } \\
\text { dibutuhkan } \\
\text { penelitian dalam }\end{array}$ & (8) \\
\hline & Jumlah sampel & 5 \\
\hline
\end{tabular}

Sumber: data sekunder diolah

Lima bank yang terpilih sebagai sampel yaitu BNI Syariah, Bank Mega Syariah, Bank Syariah Mandiri, BRI Syariah dan Bank Bukopin Syariah. Jumlah total data yang terkumpul selama periode penelitian adalah 75 .

Regresi berganda harus memenuhi uji prasyarat análisis berupa uji asumsi klasik agar memenuhi kaidah BLUE (Best Linear Unbiased Estimator). Uji normalitas dilakukan menggunakan One Sample Kolmogorov Smirnov. Berdasarkan pengujian yang dilakukan residual persamaan regresi memiliki nilai signifikansi sebesar 0,200 yang berarti lebih besar daripada alpha sebesar 5\% sehingga residual regresi terdistribusi normal. Pengujian selanjutnya adalah deteksi autokorelasi yang dilakukan melalui uji Durbin Watson. Nilai Durbin Watson sebesar 1,873. Jumlah data sebanyak 75 dan variabel independen sebanyak 4. Pada level 5\% diperoleh nilai $\mathrm{d}_{\mathrm{L}}=1,515$ dan $\mathrm{d}_{\mathrm{U}}=1,739$. Dengan demikian nilai DW sebesar 1,873 terletak antara $d_{U}<D W<4-d_{U}$ dan data terbebas dari masalah autokorelasi. Pendeteksian multikolinearitas dilakukan dengan melihat nilai Tolerance dan VIF. Semua variabel independen memiliki nilai Tolerance di atas 0,1 dan nilai VIF di bawah 10. Hal ini menunjukkan bahwa persamaan regresi tersebut terbebas dari masalah multikolinearitas. Sementara pengujian heteroskedastisitas dilakukan dengan metode Glejser. Hasil pengujian menyimpulkan bahwa tidak ada satu pun koefisien regresi variabel independen yang memiliki signifikansi kurang dari 5\%. Dengan demikian maka regresi memenuhi asumsi homoskedastisitas. Setelah regresi memenuhi persyaratan asumsi klasik maka kemudian dilakukan analisis regresi linier 
berganda untuk menguji semua hipótesis yang diajukan.

Tabel 2. Hasil Analisis Regresi

\begin{tabular}{lcrc}
\hline Variabel & KoefisienRegresi & t-hitung & Signifikansi \\
\hline Konstanta & $-9,849$ & $-2,965$ & 0,004 \\
\hline PDPK & 0,052 & 2,083 & 0,041 \\
\hline FDR & 0,050 & 3,233 & 0,002 \\
\hline CAR & 0,103 & 4,039 & 0,000 \\
\hline BOPO & $-9,829 \mathrm{E}-8$ & $-0,173$ & 0,863 \\
\hline
\end{tabular}

F hitung $=7,305$

Signifikansi $=0,000$

Adjusted $\mathrm{R}^{2}=0,254$

Sumber: data sekunder diolah

1. Pengaruh proporsi dana pihak ketiga (PDPK) terhadap Profit

Distribution Management

Berdasarkan tabel 2, terlihat bahwa koefisien variabel proporsi dana pihak ketiga adalah sebesar 0,052 dengan nilai signifikansi sebesar 0,041, yang berarti lebih kecil dibandingkan tingkat signifikansi yang disyaratkan sebesar 5\%. Dengan demikian maka disimpulkan bahwa variabel proporsi dana pihak ketiga berpengaruh positif dan signifikan terhadap Profit Distribution Management. Besaran proporsi dana pihak ketiga menunjukkan banyaknya dana yang bersumber dari masyarakat yang berhasil dihimpun oleh bank dalam bentuk tabungan, giro atau deposito. Apabila dana pihak ketiga yang dihimpun oleh bank kecil, hal ini akan menghambat jalannya fungsi bank.

Semakin besar dana pihak ketiga yang dimiliki bank maka bank mempunyai cukup dana untuk disalurkan ke pembiayaan yang menjadi sumber pendapatan bank. Pembiayaan bank syariah dapat disalurkan dengan akad bagi hasil, jual beli dan atau sewa-menyewa. Dari akad bagi hasil, bank mendapatkan pendapatan bagi 
hasil, sedangkan dari akad sewa bank akan memperoleh biaya sewa dan dari akad jual beli bank mendapat margin keuntungan. Semakin besar tingkat keuntungan yang diperoleh bank maka proporsi bagi hasil yang diberikan juga semakin besar. Temuan dari penelitian ini memperkuat hasil sebelumnya yang diperoleh Rizaluddin dan Dodik (2013), Kartika (2014) maupun Wafaretta dan Rosidi (2015), yang menyatakan bahwa proporsi dana pihak ketiga berpengaruh positif dan signifikan terhadap Profit Distribution Management.

2. Pengaruh efektivitas dana pihak ketiga (FDR) terhadap Profit Distribution Management.

Sesuai dengan hasil pada tabel 2, diperoleh koefisien regresi sebesar 0,050 dengan nilai signifikansi sebesar 0,002. Nilai signifikansi ini lebih kecil dibandingkan tingkat signifikansi yang disyaratkan sebesar 5\%. Oleh karena itu efektivitas dana pihak ketiga yang diproksikan dengan financing to deposit ratio berpengaruh positif dan signifikan terhadap Profit Distribution Management. Semakin besar nilai financing to deposit ratio mengindikasikan bahwa bank semakin efisien dalam menyalurkan pembiayaan dari dana yang telah dihimpun, sehingga pendapatan yang diperoleh bank juga akan mengalami peningkatan. Tingginya pendapatan mendorong semakin besarnya dana bagi hasil bank dan profit distribution yang diterima nasabah semakin besar.Hasil penelitian ini mendukung temuan studi. Hasil ini sesuai dengan penelitian Kartika (2014) yang menunjukkan pengaruh positif financing to deposit ratio terhadap Profit Distribution Management.

3. Pengaruh kecukupan modal (CAR) terhadap Profit Distribution Management

Koefisien regresi variabel kecukupan modal yang diproksikan dengan Capital Adequacy Ratio adalah 0,013 dengan nilai signifikansi sebesar 0,000 yang berarti lebih kecil dibandingkan tingkat 
signifikansi yang disyaratkan sebesar 5\%. Berdasarkan hasil ini ditarik kesimpulan bahwa kecukupan modal berpengaruh positif dan signifikan terhadap Profit Distribution Management. Kecukupan modal merupakan salah satu indikator tingkat kesehatan bank. Semakin besar nilai CAR maka semakin besar pula kemampuan bank untuk menutup risiko kerugian yang mungkin timbul dari penanaman aktiva produktif. Akad kegiatan penanaman asset produktif di bank dapat berupa mudharabah, murabahah dan ijarah. Dari akad mudharabah bank sebagai penyedia dana berkewajiban menanggung seluruh kerugian apabila usaha yang diberikan pembiayaan mengalami kerugian. Pada akad murabahah kerugian yang diterima berupa tidak dibayarnya seluruh barang yang sudah diberikan di awal akad. Sedangkan kerugian yang ditimbulkan dari ijarah (sewa) yaitu berupa rusaknya barang-barang yang disewakan kepada nasabah, sehingga bank harus mengeluarkan biaya perawatan. Apabila penanaman dalam aset produktif tersebut mengalami kerugian, modal digunakan untuk menanggung risiko atau menutup kerugian. Penggunaan modal untuk menutup risiko mengakibatkan pendapatan yang didapatkan dari pembiayaan selain aset produktif tidak berkurang nominalnya, sehingga bagi hasil kepada nasabah tidak berkurang. Simpulan ini konsisten dengan penelitian Mulyo dan Mutmainah (2013), Evayani (2014), Hidayat (2016) dan Masruroh (2016), yang menyatakan bahwa kecukupan modal berpengaruh positif dan signifikan terhadap Profit Distribution Management bank syariah di Indonesia.

4. Pengaruh biaya operasional terhadap pendapatan operasional (BOPO) terhadap Profit Distribution Management

Mengacu pada tabel 2, diperoleh hasil berupa koefisien regresi sebesar -9,829E-8 dengan tingkat signifikansi sebesar 0,863 . Nilai signifikansi tersebut lebih 
besar dibandingkan tingkat signifikansi yang disyaratkan sebesar 5\% sehingga disimpulkan bahwa biaya operasional terhadap pendapatan operasional tidak berpengaruh terhadap Profit Distribution Management. Hasil penelitian tersebut bertentangan dengan simpulan yang diperoleh dari penelitian Rizaludin dan Dodik (2013) yang menyatakan bahwa BOPO berpengaruh negatif dan signifikan terhadap Profit Distribution Management. Hasil yang tidak signifikan ini dapat disebabkan oleh nilai rata-rata variabel BOPO yang cukup tinggi dalam penelitian ini yaitu lebih dari 90\%. Angka ini mengindikasikan bahwa bank tidak dapat mengelola sumber dana dan aktiva yang dimiliki untuk memperoleh laba. Menurut Bank Indonesia angka yang ditetapkan untuk rasio BOPO adalah dibawah 90\%. Apabila biaya yang dikeluarkan tinggi dan bagi hasil yang diperoleh relatif rendah, maka mengakibatkan manajer tidak akan termotivasi untuk melakukan Profit Distribution Management yang tinggi, karena akan sulit menutupi kemungkinan risiko yang akan ditimbulkan.

Uji F dalam penelitian ini memperlihatkan angka sebesar 7,305 dengan nilai signifikansi sebesar 0,000 yang bermakna bahwa terdapat goodness of fit dari model regresi sehingga variabel independen yang digunakan dalam model dapat digunakan untuk memprediksi Profit Distribution Management. Nilai Adjusted $R^{2}$ sebesar 0,254 mengindikasikan bahwa variasi Profit Distribution Management yangd apat dijelaskan oleh proporsi dana pihak ketiga, efektivitas dana pihak ketiga, kecukupan modal dan rasio biaya operasional terhadap pendapatan operasional adalah sebesar 25,4\% sedangkan sisanya sebesar 74,6\% dijelaskan oleh variabel lain yang tidak digunakan dalam penelitian ini.

\section{Kesimpulan}

Hasil yang diperoleh dari penelitian ini menyimpulkan bahwa proporsi dana pihak ketiga, efektivitas dana pihak ketiga yang diproksikan dengan financing to deposit ratio dan kecukupan modal yang diproksikan dengan capital adequacy ratio (CAR) berpengaruh positif dan signifikan 
terhadap Profit Distribution Management. Sedangkan rasio biaya operasional terhadap pendapatan operasional tidak berpengaruh terhadap Profit Distribution Management. Dari penelitian ini dapat diidentifikasi beberapa keterbatasan yaitu penelitian ini hanya menggunakan empat variabel sebagai ukuran kinerja keuangan bank syariah dan terbatas baru menggunakan faktor internal bank sebagai determinan Profit Distribution Management. Penelitian selanjutnya dimungkinkan dapat menambah variabel internal lainnya yang mencerminkan kinerja bank syariah secara lebih komprehensif maupun menggunakan variabel eksternal. Penambahan variabel independen yang diteliti juga diharapkan dapat meningkatkan nilai Adjusted $R^{2}$ yang masih relatif kecil dalam penelitian ini. Temuan penelitian ini membawa implikasi bahwa bank perlu memperhatikan faktorfaktor yang mempengaruhi profitabilitas karena akhirnya akan menentukan besaran Profit Distribution Management.

\section{DAFTAR USTAKA}

Antonio, Muhammad Syafi'i. 2001. Bank Syariah dari Teori Ke Praktek. Jakarta : Gema Insani Pers-Tazkia.
Farook et al. 2009. "Profit Distribution Management By Islamic Banks: An Empiremental Investigation". The Quarterly Review of Economic and Finance. 52, 333-34.

Hermanu, Dery Khairyl dan Erma Setiawati. 2015. "Faktor-Faktor yang Mempengaruhi Profit Distribution Management pada Bank Syariah Di Indonesia Periode 20102014". Skripsi Tidak Dipublikasikan. Universitas Muhammadiyah Surakarta.

Hidayat, Wahyu Eko. 2016. "Faktor-Faktor yang Mempengaruhi Profit Distribution Management Bank Syariah di Indonesia". Jurnal Publikasi Universitas Sunan Kalijaga Yogyakarta.

Husnelly. 2003. "Analisis Faktor-Faktor Yang Mempengaruhi Investasi Dana Masyarakat Pada Bank Syariah (Studi Kasus Pada BSM)". Tesis Tidak Dipublikasikan. PSKTT UI.

Karim, A. dan Afif. 2006. "Islamic Banking Behaviour in Indonesia: A Qualitative Approach". 6th Conference on Islamic Economics and Finance. Jakarta, Indonesia.

Mangkuto, Imbang J. 2004. "Pengaruh Tingkat Suku Bunga Deposito Bank Konvensional dan Tingkat Pendapatan Deposito Mudharabah Terhadap Pertumbuhan Deposito di Bank Muamalat. Tesis Tidak Dipublikasikan. PSKTT UI

Masruroh, Fitriana. 2016. Analisis Profit Distribution Management Bank Syariah 
di Indonesia. Artikel Ilmiah Mahasiswa. Universitas Jember.

Mawardi, N. 2005. Faktor-Faktor Yang Mempengaruhi Penetapan Return Bagi Hasil Deposito Mudharabah Muthlaqah. Tesis Tidak Dipublikasikan. Universitas Indonesia.

Mulyo, G. P. dan Mutmainah, S. 2013. "Determinan Profit Distribution Management Bank Syariah di Indonesia Periode 2008-2011". Jurnal Ekonomi, Manajemen dan Akuntansi Islam. Volume 1 Nomor 1, 1-74. Universitas Diponegoro. Semarang

Rifadil, T. dan Said Muniruddin. 2017. "Analisis faktor-faktor yang Mempengaruhi Profit Distribution Management pada Bank Umum Syariah Tahun 2012-2015". Jurnal Ilmiah Mahasiswa Ekonomi Akuntansi (JIMEKA). Vol. 2, No. 3, 140-153.

Rini. 2000. Simpanan Bagi Hasil di Bank. Safir Senduk \& Rekan

Rizaludin, M dan Dodik, S. 2013. "Analisis Pengaruh Variabel-Variabel Determinan Atas Profit Distribution Management Terhadap Para Nasabahnya Pada Bank Syariah di Indonesia”. Jurnal Publikasi Universitas Indonesia.
Rivai, V., dan Arifin, A. 2010. Islamic Banking : Sebuah Teori, Konsep, dan Aplikasi. Jakarta : Bumi Aksara.

Sugiyono. 2008. Metode Penelitian Bisnis. Bandung: Alfabeta.

Sundararajan. 2005. "Issues in Managing Profit Equalization Reserve and Investment Risk Reserve in Islamic Bank". Journal of Islamic Economics Banking and Finances, 4, 1-1

Wafaretta, Vega dan Rosidi. 2015. "The Impacts of Bank Characteristic on Profit Distribution Management on Islamic Banks". Social and Behavioral Sciences. 219, 769-776.

Yahya M. 2011. Perilaku Menabung di Perbankan Syariah di Jawa Tengah. Desertasi Tidak Dipublikasikan. Universitas Diponegoro Semarang. 